\title{
Exploring Biographies. Ancient Egyptian Funerary Statuettes at the Museum of Cultural History, University of Oslo
}

\author{
Saphinaz-Amal Naguib
}

\begin{abstract}
Small funerary statuettes shaped as mummiform figurines are among the most common ancient Egyptian artefacts to be found in museums of cultural history worldwide. The Museum of Cultural History, University of Oslo $(M C H)$ is no exception. The present article explores the biographies of material culture, materiality, objectification and shifts in meaning. It probes the many ways small artefacts, often categorized as 'minor art objects' of no importance, provide us with valuable insights into ancient Egyptian beliefs, society and culture. Selecting a few pieces from different periods, it delves into the multi-layered narratives and intersecting storylines where the objects' biographies are tied to a web of relations across time and space as well as to the history of the ancient Egyptian collection at the MCH. The article discusses questions related to museological and heritage management, and addresses ethical issues concerning the provenance and ownership of archaeological artefacts in museums.
\end{abstract}

This essay is about the biographies of material culture, materiality, objectification and shifts in meaning. In it, I examine one of the most common types of ancient Egyptian artefacts to be found in museums of cultural history worldwide. ${ }^{1}$ The Museum of Cultural History, University of Oslo $(\mathrm{MCH})$ is no exception. ${ }^{2}$ The objects in question are small mummiform figurines that are also known by their ancient appellations shabti, shawabti and ushebti. These statuettes were made of various materials such as wax, clay, wood, stone or faïence, and from the Middle Kingdom (2055-1650 BCE) to the Ptolemaic Period (332-30 BCE) they were part

\footnotetext{
${ }^{1}$ The appellation 'museum of cultural history' is a generic denomination encompassing universal survey museums, museums of history and archaeology, museums of ethnography and folklore as well as city museums and eco-museums.

${ }^{2}$ The publication of the funerary statuettes at the $\mathrm{MCH}$ was part of the international project Corpus Antiquitatum Aegyptiacarum (CAA); Naguib 1985.
} 
of the funerary equipment of the deceased. ${ }^{3}$ In the following, I reflect on the many ways these small artefacts, often categorized as 'minor art objects' of no importance, provide us with valuable insights into ancient Egyptian beliefs, society and culture, and convey a multitude of multi-layered narratives and intersecting storylines where their own biographies are tied to a web of relations across time as well as to the history of the ancient Egyptian collection at the $\mathrm{MCH} .{ }^{4}$ I will not attempt to review all the funerary statuettes at the museum, but instead illustrate my arguments with some examples from the collection at the $\mathrm{MCH}$.

Exploring the biographies of things involves perceiving them not merely as passive objects to which meaning is given, but also as active agents that can influence social relations. It brings to the fore the manner in which relations between people and things change over time and place. ${ }^{5}$ In the context of museums it entails, among other things, studying objects in transition, with shifting meanings and functions, to trace their movements and trajectories across time, space and societies. The biographic perspective opens up possibilities for thinking differently about artefacts in museums, their provenance, craftsmanship and period, and how they relate to other objects, to sites, to people and to cultural practices. Hence, it involves considering the materiality of things and probing the relationships between people and material culture in a given culture at a certain period in addition to analysing their physical properties, their forms and style. ${ }^{6}$ Materiality is tied to processes of objectification and to what Robert Armstrong has described as the affective presence of things. According to him 'affecting things' are intentionally made cultural artefacts that are imbued with power. They trigger emotions and convey sets of values and beliefs, which are firmly embedded in a particular context. ${ }^{7}$ Ancient Egyptian culture had its own perception of materiality, its religious, ontological and social significations. Texts such as those inscribed on funerary statuettes had their own materiality and were integral to the object. ${ }^{8}$ They explicate the ideas that have been given concrete forms and how they have altered over time. ${ }^{9}$ These ideas pertain to life in an agrarian society, to beliefs related to the afterlife and to the notion of person and his/her transfiguration.

3 Aubert \& Aubert 1974; Milde 2012; Schneider 1977. I adopt here the chronology proposed by Shaw 2001. The ancient Egyptian terms are transcribed into English and not transliterated.

${ }^{4}$ Naguib 1981.

${ }^{5}$ Kopytoff 1986; Gosden \& Marshall 1999.

6 Meskell 2004.

7 Armstrong 1971.

8 Meskell 2004, 7.

9 Tilley 2006, 60-62. 


\section{Enduring landscape}

According to the ancient Egyptian worldview, creation was perceived as a constant process determined by the juxtaposition of cyclic and linear time. The rising and setting of the sun, the waning and waxing of the moon and the annual floods of the Nile on which all agriculture depended pertained to the incessant repetition of cycles. Concurrently, all life was subjected to linear time, to aging, death and regeneration. The idea of constant 'becoming' or transformations, of going through different stages of transfigurations even after death, was central to ancient Egyptian thought. It was expressed by the concept of kheperu, which was written with the sign of the scarab and applied to nature, animals, humans and also gods. ${ }^{10}$ Thus, death in ancient Egyptian thought was not an end but rather the continuation of an ongoing process.

Our knowledge of the ancient Egyptian afterlife is first and foremost based on religious texts and visual representations found on the walls of some pyramids and various tombs, on coffins and on papyri. These documents reveal that the landscape in the Netherworld was very similar to that on earth, with a subterranean river and land to be cultivated. It was believed that the sun-god Râ sailed in the Netherworld at night illuminating it with his rays and thus bringing it to life. Each hour of the night was associated with a geographic region, which was organized as on earth and consisted of lands donated by the sun god to the dead to be farmed. ${ }^{11}$ Life in the Netherworld was viewed as a reflection of life on earth, and the dead were expected to carry out the agricultural work needed to maintain the productiveness of the land. Hans Schneider depicts ancient Egypt as an 'irrigation civilization' where life was regulated by the rhythm of the Nile and its innundation. During and after the annual flood, the population was subject to compulsory labour. ${ }^{12}$ The work to be carried out was mainly the reconstruction of the irrigation basins that had been destroyed by the Nile waters and the maintenance of the irrigation system, preparing the fields for cultivation and irrigating the land. ${ }^{13}$ This was heavy work and it must have been tempting to find ways out of it.

\section{The transfiguration of the person}

In ancient Egyptian conceptual thinking the person was perceived as a composite whole, a monistic unit with material and immaterial manifestations or 'modes' of existence, some of which became active only after death. ${ }^{14}$ The body and the heart were the most important material aspects of the person, and the preserved body, that is the mummy (sah), ensured the survival of the person after death. The heart

\footnotetext{
10 Assmann 2001, 60.

11 Hornung 1999.

12 Katary 2012.

13 Butzer 1976; Schneider 1977, 9-13.

14 Naguib 1994.
} 
(ib, haty) was perceived as the centre of life, the seat of the mind, memory, emotions and conscience. It represented the essence of the individual, the totality of a person's life and behaviour, and may be understood as 'the source of human free will'. ${ }^{15}$ The chapters in the Book of the Dead that address the heart throughout the last judgement intimate that, during the trial, the heart of the deceased acts as a witness and may in that capacity reveal the negative deeds of its former self. Hence, during the weighing of the heart the deceased reminds the heart that, together, they have gone through successive phases of life or 'transformations' (kheperu), and begs it not to turn against him/her. This suggests that the heart was also associated with individual memory. ${ }^{16}$

The material and immaterial aspects of the individual were brought together in the name (ren), which assured the individual's existence and identity in life and after death. The preservation of the name was essential for the survival of the person in the afterlife as well as in the memory of the living. The physical manifestations of the person were completed by immaterial modes of existence as the $k a$, the $b a$, the shadow and the akh.

The ka needed to inhabit a concrete form, which could be either the mummy or an effigy of the deceased. It came into existence at birth and was portrayed as an exact copy of the individual, and scenes show the ram-headed god Khnum fashioning the child and its $k a$ on his potter's wheel. The $k a$ is viewed as the vital energy, a kind of genetic bond that was passed on from one generation to the next and that was temporarily broken up at death. ${ }^{17}$ To restore the generational tie and to survive in the afterlife the deceased needed to 'go to his/her ka'. ${ }^{18}$ For this to happen a number of rituals had to be performed. Food offerings and libations had to be made at the tomb, which was considered the abode of the ka and the place where the passage from life to death was concluded.

The tomb was also the place where that other aspect of the person, the $b a$, would reunite with the mummy and meet the living that came to visit the deceased. The $b a$ had the same physical needs of food, drink and sexual activity as the living person. It was represented as a bird with a human head with the same features as the deceased and sometimes also with arms and hands. The $b a$ could dissociate itself from the body, move about freely and take any shape it wanted. While the ka referred to the interior communication of the individual with him/herself, the $b a$ served as an agent of communication between the deceased and the exterior world. ${ }^{19}$ I have inferred elsewhere that the $b a$ combined the perception of the individual's identity and the memory of him/her self. ${ }^{20}$ To these modes of existence

\footnotetext{
15 Hornung 1992, 177.

16 Naguib 1997b.

17 Naguib 1994.

18 Assmann 2005, 97.

19 Assmann 1979, 71; te Velde 1990, 92.

20 Naguib 1997a.
} 
one should add the shadow $(\operatorname{shwy} t)$, which only left its owner at death and which conveyed a sense of mobility and coolness. In Ptolemaic times the notion of the person became less complex and the name was often identified with the $k a$, while the $b a$ was equated with the shadow.

After having been successfully judged and found 'true of voice', and having gone through all the tests and obstacles of the Netherworld, the fortunate deceased would reach a different state of existence. S/he would integrate the cyclic configurations of the cosmos and become an akh, namely a 'transfigured one' or 'illuminated spirit', and enjoy eternal life.

\section{Giving concrete forms to ideas}

During the Old Kingdom (2682-2181 BCE) and early Middle Kingdom (2055-1650 BCE) those who could afford it placed statues, known in Egyptological terminology as $k a$-statues, in the tombs. The $k a$-statue showed the individual as a living person and was both the image of the deceased and the image of a servant offering the food. It acted as both the recipient of offerings and the provider of food for the ka of the deceased. ${ }^{21}$ In addition to the ka-statues tombs were often equipped with statues of servants carrying out their chores, especially those tied to the provision and preparation of food. Servant statuettes disappeared in the course of the Middle Kingdom. This coincides with the appearance of the small mummiform figurines known as shabti and of a new type of statue representing the deceased that was no longer dressed in the clothes of the living, but as a mummy. ${ }^{22}$ The new practice indicates a change in ideas and rituals concerning the afterlife and the spreading of privileges that until then had been limited to the king. ${ }^{23}$ The meaning of the term shabti is uncertain. It either derives from the word for wood, shebet, or from the verb shebu, 'to nourish oneself', 'to eat', with the word shab as the substantive for food. The shabti inscription begins normally with the formula sehedj-Usir, meaning 'illuminated Osiris', followed by the name of the deceased and the Spell for causing shabtis to do work for their owner in the realm of the dead, or spell 472 (often incomplete) of the Coffin Texts. The spell gives an idea as to the function of the statuettes:

O you shabti which has been made for $\mathrm{N}$, if this $\mathrm{N}$ should be counted for the removal of a dam and for the levelling of a district, to irrigate the riparian lands and to turn over new fields ... 'See, here I am', you shall say to any messenger, I shall come for this $\mathrm{N}$, in place of him. Take your mattocks, your hoes, your yokes and your baskets in your hands! — as a man at his duties. To be spoken over an image of the owner as he

${ }^{21}$ Schneider 1977, 20.

22 Milde 2012; Schneider 1977, 62; Taylor 2001, 112-117.

${ }^{23}$ Smith 2009, 4-11. 
was on earth, made of tamarisk or zizyphus wood and placed (in) the chapel of the deceased. ${ }^{24}$

The spell ensured that if the owner of the shabti was called upon at any time to do any kind of compulsory labour tied to agriculture and irrigation the shabti would respond and perform the duty instead of its owner. The text clearly specifies the type of material that was to be used to make a shabti and prescribes that the spell should be recited over a wooden statue of the owner 'as on earth', hence as a living person. ${ }^{25}$ It also suggests that the shabti had taken over some of the qualities of the $k a$-statues, and as such was conceived as a substitute for the deceased.

Traditions do not stand still but are continuously appraised, modified and adapted to new ideas and to new ways of life. This was also true in antiquity. As mentioned above the practice of including mummiform statuettes among the funerary goods lasted until the Ptolemaic Period but their meaning and function changed with time. During the seventeenth Dynasty (1650-1550 BCE) the appellation shawabti was introduced but was never widely used. The etymology of the word may have been shawab meaning 'persea tree', referring to one of the types of wood used to make the statuettes. The eighteenth Dynasty (1550-1295 BCE) brought with it some innovations that lasted throughout the New Kingdom (15501069 BCE). The statuettes were still made of different materials with an overall preference for clay and faience. ${ }^{26}$ The iconography changed from that period onwards, and the figurines are shaped with crossed arms. They are usually holding agricultural implements in each hand and carrying a basket on their backs. Some are provided with separate models of agricultural tools such as hoes, adzes, yoke poles, baskets and even moulds for mud bricks. The great majority of figurines are mummiform, but at the end of the eighteenth Dynasty and the beginning of the nineteenth Dynasty (1295-1069 BCE) some do wear the clothes of the living. The number of statuettes varied according to the wealth of their owner. The usual number ranges from one to three statuettes; some of them are provided with small individual coffins or have been placed in models of shrines. The inscription consists of the sehedj-Usir formula followed by the name and title(s) of the deceased and chapter six from the Book of the Dead, or rather excerpts from one of the various versions of that chapter. The shabti spell from the Coffin Texts, codified as chapter six of the Book of the Dead, had by then become the standard text to be inscribed on the shabtis. In some versions the text addresses the shabti as hem, which means servant. This indicates a new perspective as to the function of the funerary statuettes and hints that, along with the appearance of tools in the course of the New Kingdom, they had somehow acquired a double role of substitute and servant of the deceased.

${ }^{24}$ After Faulkner 1985 [1972], 106 and Schneider 1977, 50 and 53.

25 The MCH has no funerary statuettes from this period.

${ }^{26}$ For the technology in making faience, see Nicholson 2009. 


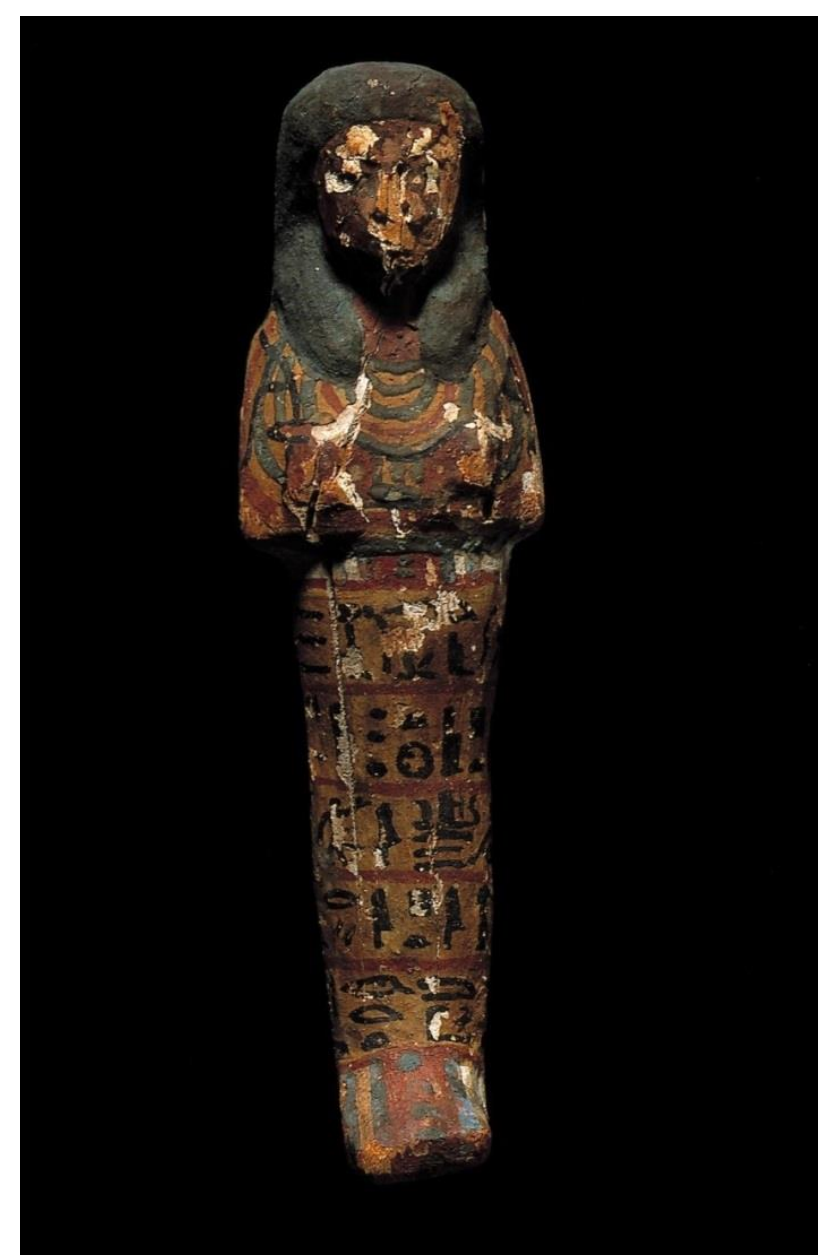

Fig. 1 Shabti of Amenemwia. Photo: Museum of Cultural History, University of Oslo C. Inv. C47028.

There are two funerary shabtis from the New Kingdom at the MCH. The polychrome statuette of the wab-priest, Amenemwia, from the nineteenth dynasty is in wood (Fig. 1). ${ }^{27}$ The body is in yellow-ochre and the tripartite wig, the tools and the text are in black. The face has been damaged. The shabti has crossed arms and holds a hoe in each hand. A basket is placed diagonally on its back. The text, which is a short rendering of one of the versions of the Book of the Dead, chapter six, is written in hieroglyphs and consists of five horizontal lines reading from right to left. The beginning and the end of each line are separated at the back by a column shaped as a net. The statuette was given to the museum in 1903-1904 by the first Norwegian Egyptologist, Professor Jens C. Lieblein (1827-1911).

${ }^{27}$ Naguib 1985, 1:1-1:3 (inv. C47028/EM12651). 


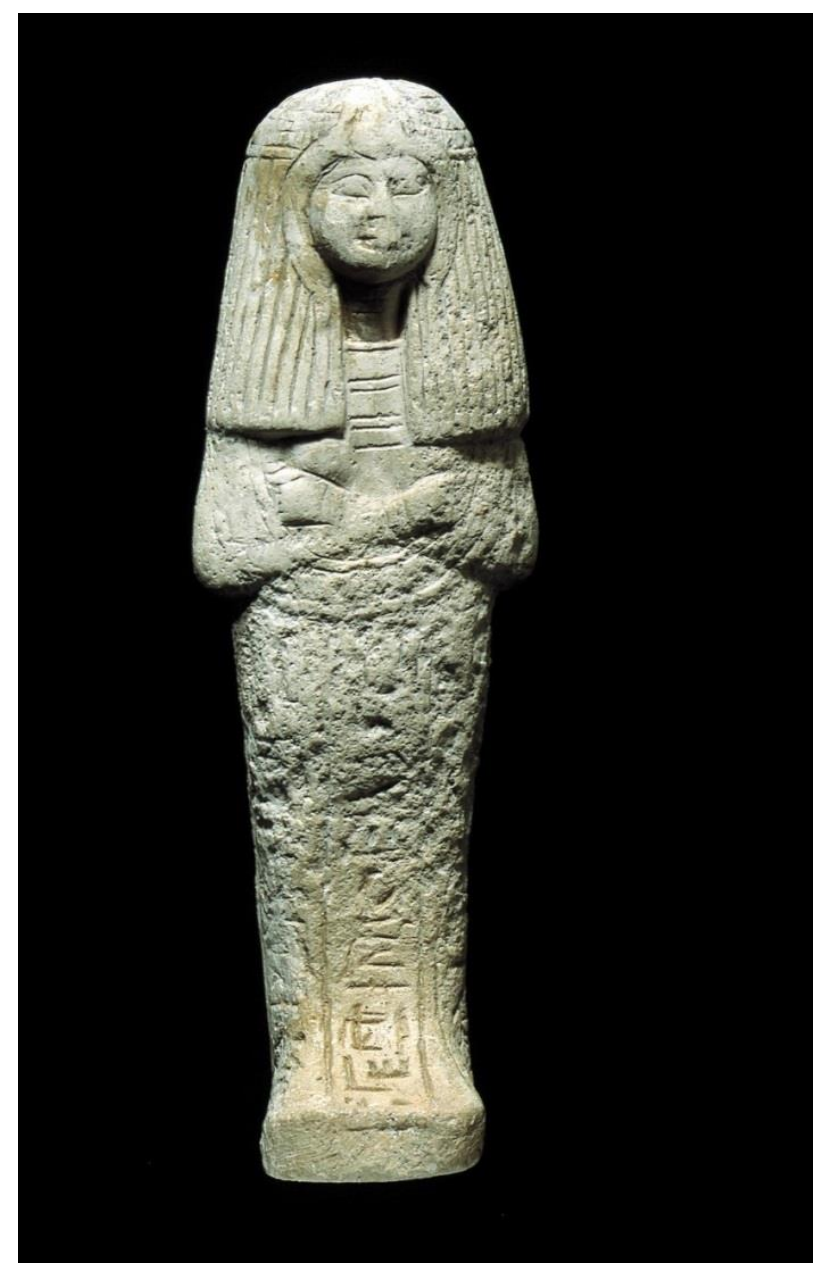

Fig. 2 Shabti of Urnuru. Photo: Museum of Cultural History, University of Oslo C. Inv. C47011.

The statuette of a woman called Urnuru is in limestone and dates from the nineteenth-twentieth dynasties (Fig. 2). ${ }^{28}$ There are traces of paint on the body and on the big ornamental wig. The text is a short rendering of chapter six of one of the versions of the Book of the Dead, and is incised into six columns of hieroglyphs beginning from under the wig. It is read from right to left starting from the centre front. The figurine was given to the museum between 1867 and 1870 by Daniel Franco, a businessman living in Alexandria. The donation was concluded through the mediation of Lieblein.

${ }^{28}$ Naguib 1985, 1 and 4-6 (inv. C47011/EM 2231). 
Although we know who the donors of these two artefacts are, their provenance remains a mystery. Unless other documents belonging to Amenemwia and Urnuru are (re)discovered and the puzzles of the various pieces of their funerary equipment are resolved, the fact that the original context is unknown puts a limit on our knowledge about these two individuals and their social environments (see below).

\section{The answerers take over}

The twenty-first Dynasty (1069-945 BCE) marked a turning point in the perception of funerary statuettes. From now on they were called ushebti or 'answerer'. The term probably derives from the verb usheb, 'to answer'. It became the standard word used to designate the figurines in chapter six of the Book of the Dead, and was used until the Ptolemaic period when the last ushebtis were made. The change of name indicates that the statuettes were considered the servants of the deceased rather than his/her substitutes. As servants they answered when summoned to duty and obeyed the orders given to them.

Due to the increase in demand for funerary statuettes, ushebtis were now mass produced from a mould in clay or faience. During the twenty-first dynasty there was a large preference for blue faience and the statuettes with an intense blue glaze, often designated today as 'the Deir el Bahari blue', were particularly popular. The figurines are now smaller in size, the modelling generally mediocre and their features less individualized. Details such as the eyes, the head band, the agricultural tools and the texts are painted in black. While in earlier periods there were just a few statuettes buried with the deceased, from the twenty-first Dynasty onwards their number could be as many as 401 consisting of 365 workers, one for each day of the year, and thirty-six overseers each one heading a gang of ten workers. ${ }^{29}$ The workers are shaped as mummies and equiped with agricultural tools such as hoes, baskets, mattocks and yokes. The overseers wear triangular kilts, which was the dress of the living. They have an arm along the side of the body while the other arm is flexed on the chest and holds the emblem of his authority, a whip in his hand (Fig. 3).

The statuettes were placed in specially made boxes. An incomplete version of chapter six of the Book of the Dead may be inscribed in horizontal bands reading from right to left. The text makes it clear that the ushebti or 'the one who answers' is a servant expected to replace the deceased in carrying through all sorts of agricultural tasks in the afterlife.

29 The ancient Egyptian calendar was a solar calendar. The year was composed of 365 days; this was divided into twelve months, each month comprising three ten-day weeks. Five extra days, known as the epagomenal days, were added to the end of the year. 


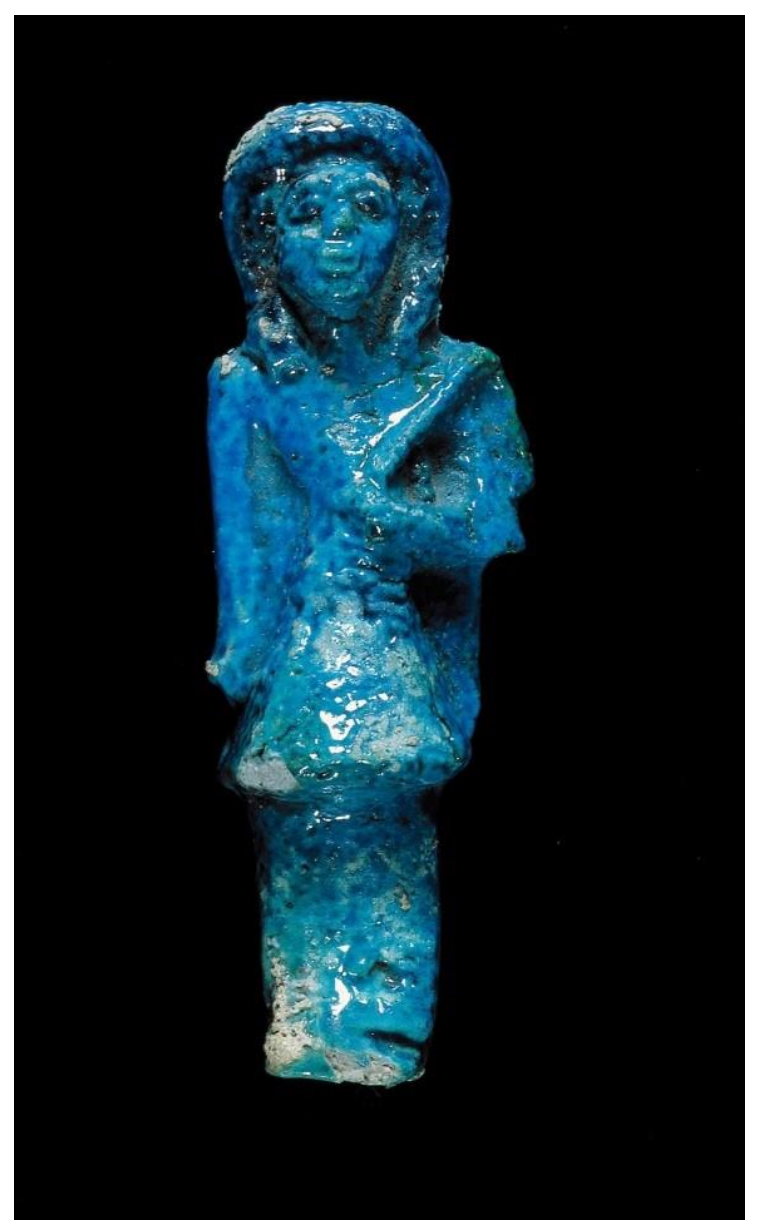

Fig. 3 Anonymous overseer of workers.

Photo: Museum of Cultural History, University of Oslo C. Inv. C47080.

O ushebti, allotted to me, if I be summoned or if I be detailed to do any work which has to be done in the realm of the dead; if indeed obstacles are implanted for you therewith as a man at his duties, you shall detail yourself for me on every occasion of making arable the fields, of flooding the banks or of conveying sand from east to west; 'Here am I', you shall say. ${ }^{30}$

In the majority of cases, however, the text on ushebtis consists of a simple vertical line painted in black cursive hieroglyphs with the formula sehedj-Usir followed by the title(s) and name of the deceased.

${ }^{30}$ Faulkner 1985 [1972], 36. 


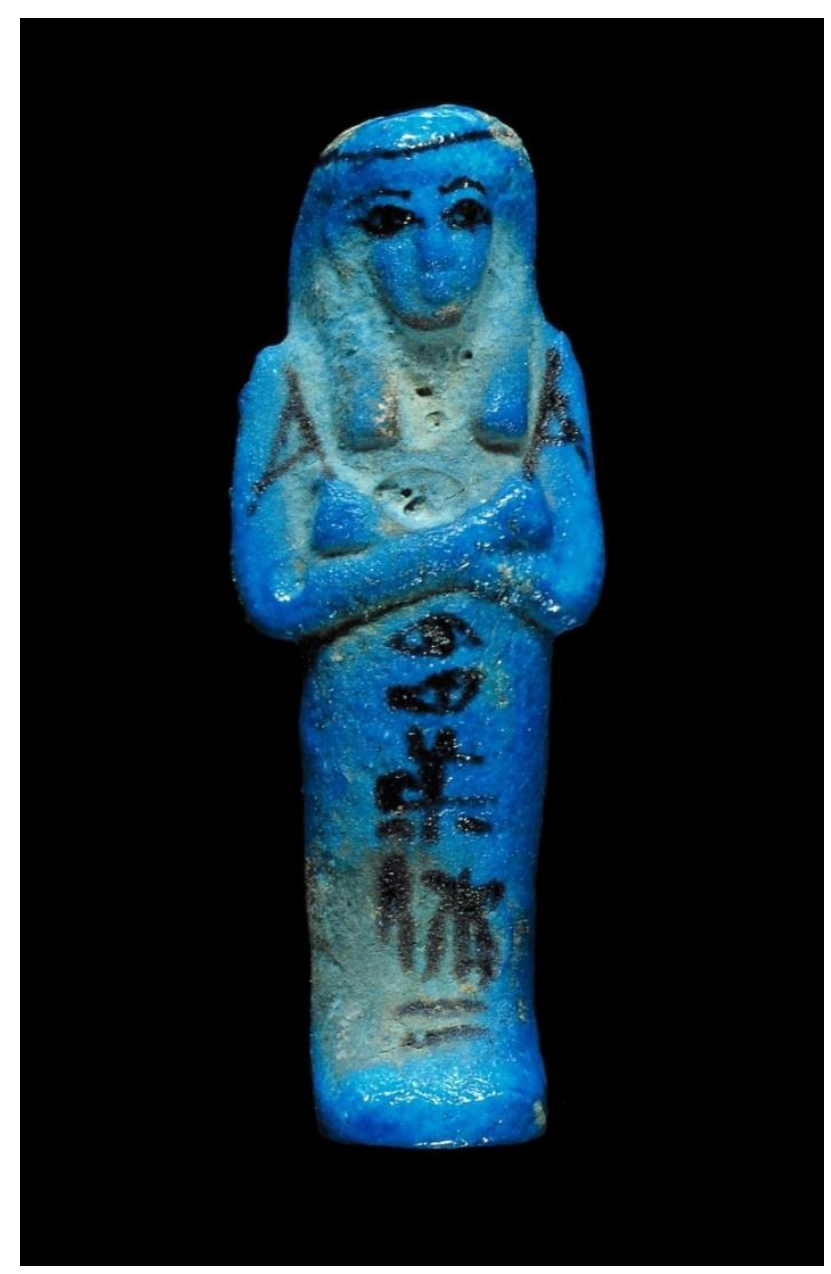

Fig. 4 Ushebti of Userhatmes. Photo: Museum of Cultural History, University of Oslo C. Inv. C47084

The MCH has forty-six ushebtis from the twenty-first Dynasty. All come from the same site, namely, the second cachette of Deir el Bahari, where 153 priests and chantresses of the god Amun had been buried. The objects at the MCH were part of the same lot that was given by the Khedive Ismail (1830-1895) to King Oscar II (1829-1907). Several scholars have undertaken to reconstruct the second cachette and to map the ways its contents have been distributed to various museums around the world. ${ }^{31}$ Without going into the details of the finds, I wish to underline that the story of the discoveries of the two cachettes at Deir el Bahari, and the role played by the Abd el Rassoul family, are among the best documented discoveries in Egyptian archaeology during the late nineteenth century. ${ }^{32}$ It has inspired modern Egyptian

\footnotetext{
31 Aubert 1998.

32 Thompson 2015, 8-10.
} 


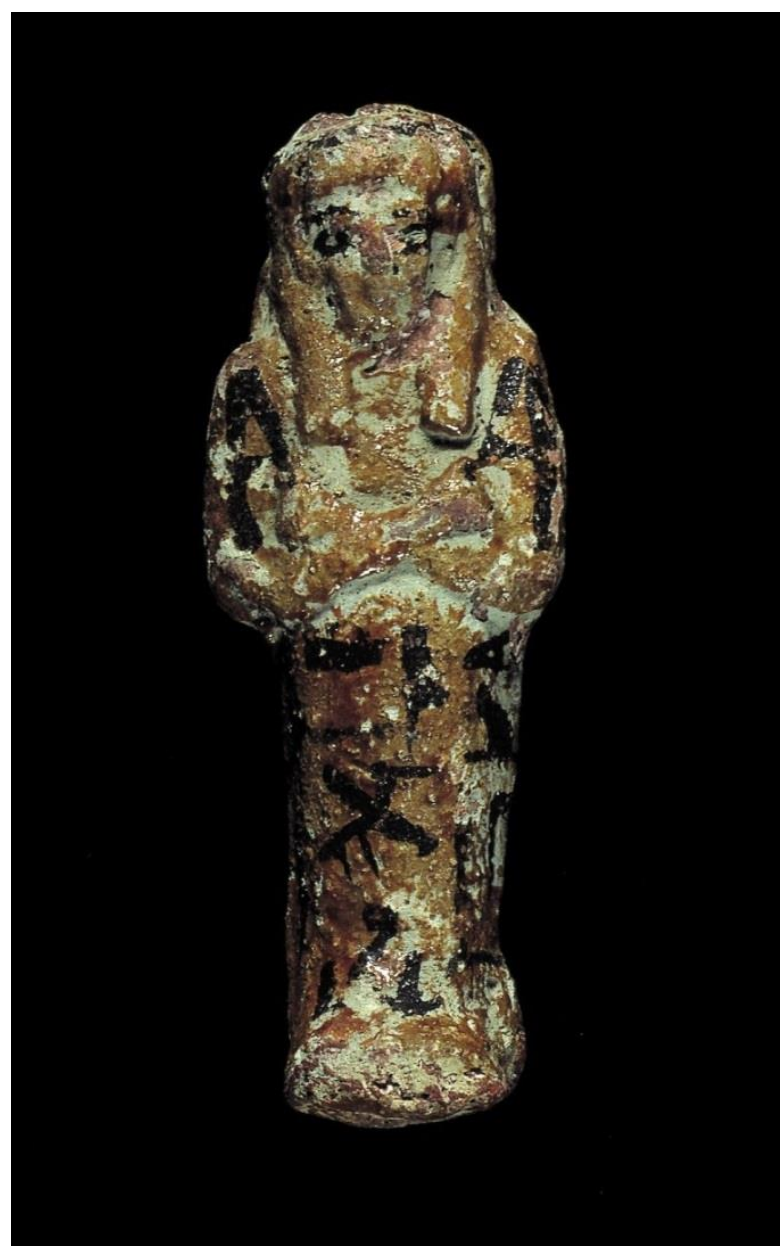

Fig. 5 Ushebti of Padiamun. Photo: Museum of Cultural History, University of Oslo C. Inv. C47063.

pharaonism and neo-pharonism movements and has been dramatized by the Egyptian film director Chadi Abdessalam in his 1969 film, al-Mumya' (The Mummy). ${ }^{33}$ Knowing the provenance of rather banal artefacts such as the ushebtis and the circumstances of the find turns them into unique objects of knowledge. Not only do they provide very valuable information about the structure of the Egyptian society, the significance of kinship and the organization of the temple of the god Amun during the the twenty-first Dynasty, but they also disclose the interconnectivity between political, social, economic and academic networks of more recent times. In addition, they have value as source material for scientific analysis. By studying the funerary group of each individual we learn, for instance, that Userhatmes was a contemporary of the High Priest of the god Amun, Menkheperre and King Psousennes I. He held a high position in the temple hierarchy as father of the god,

33 Haikal 2003, 137; Naguib 2011, 127-138. 
overseer of secrets, prophet of the god Amun, scribe of the treasury of the harem of the god Amun, and a wa'b-priest of the goddess Mut of Isheru (Fig. 4). ${ }^{34}$

Although the statuette of the father of the god, overseer of secrets, $w^{\prime} b$ priest and chief lector priest of the god Amun, Padiamun is not in blue faience but in red ware pottery, which was a cheaper material, his titles indicate that he was of no lesser importance than most of the other members of the clergy of the god Amun that were buried beside him in the second cachette of Deir el Bahari (Fig. 5)..$^{35}$

The objects found there have also imparted new insights about the place and role of women in the clergy of the god Amun during that period. Their titles reflect their social position in society as well as revealing fundamental aspects of ancient Egyptian worldview and cosmology. ${ }^{36}$ The $\mathrm{MCH}$ has four ushebtis of Merytamun, who was the daughter of the High Priest of the god Amun, Menkheperre and of the Great Superior of the sacred musical company, Isetemkheb (C). She held important positions in the clergy of the god Amun in Thebes as singer of the god Amunrasonther, nurse of the god Khonsu-pa-kered (Khons the child) and chantress of the goddess Mut, great lady of Isheru (Fig. O). ${ }^{37}$

There are also two ushebtis of her sister, Gautseshenu, at the MCH. She too was a singer of the god Amun and chantress of the goddess Mut in addition to being the great chief of the harem of the god Amun of the third phyle and great chief of the harem of the god Montu, lord of Thebes (Fig. 7). We know from other documents that she was married to Tjanefer, another high official in the clergy of the god Amun in Thebes at that time, and of whom the MCH has one ushebti. ${ }^{38}$

The iconography of ushebtis underwent some slight changes during the following dynasties, and a new style was introduced in the course of the Late Period (664-332 BCE), which continued until the end of the Ptolemaic Period. Elements from stone sculpture such as a pedestal and a back pillar are applied to ushebtis. The figurines are usually made of green faience, they are still mummiform, and the overseers have disappeared. The bodies are slender; the faces are often fashioned with care. They seem to be made as portraits of the deceased, and they smile. They hold agricultural tools in each hand and a basket attached to a cord over the left

\footnotetext{
34 Naguib 1985, 1 and 23-24 (inv. C47084/EM 8091); Naguib 1990, 269; Aston 2009, 182 TG 778 (A. 105).

35 Naguib 1985, 1 and 30-32 (inv. C47062/EM 8103, 8113); Naguib 1990, 272; Aston 2009, 184 185, TG 787 (A. 114).

36 Naguib 1990.

37 Naguib 1985, 1 and 35-37 (inv. C47077/EM 8083; C47072/EM 8094; C47075/EM 8105b; C47070/EM 8112; Naguib 1990, 134, 164, 168 and 253; Aston 2009, 175-176. TG 744 (A. 71 ). 38 Naguib 1985, 1 and 73-75 (inv. C47076/EM 8089; C47081/EM 8104b); 1 and 82-83 (C47082/EM8119); Naguib 1990, 134, 167-68, 259 and 280; Aston 2009, 194-195, TG 825 (A. 152), 194 TG824 (A.151).
} 


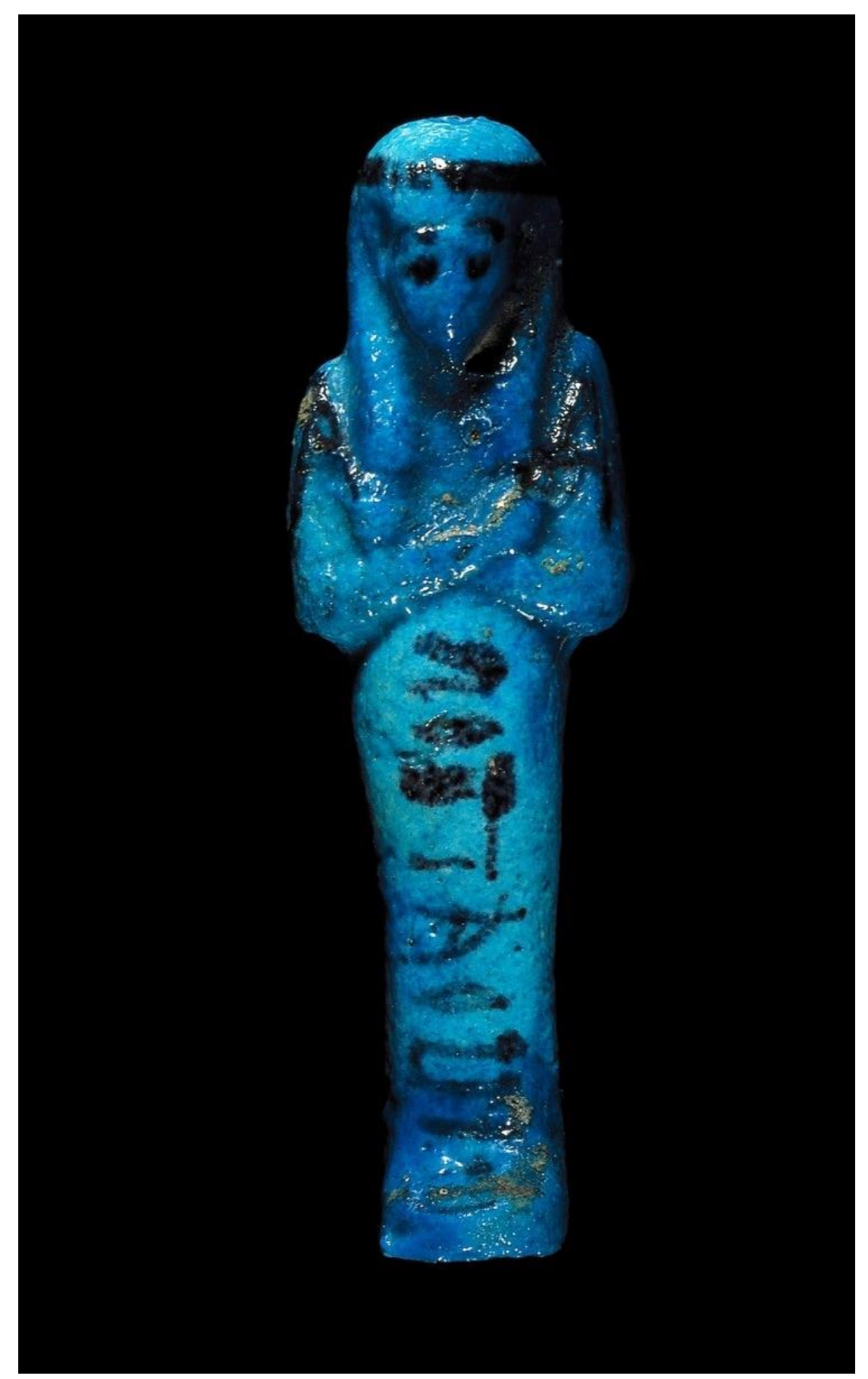

Fig. 6 Ushebti of Merytamun.

Photo: Museum of Cultural History, University of Oslo (C. Inv. C47070. 


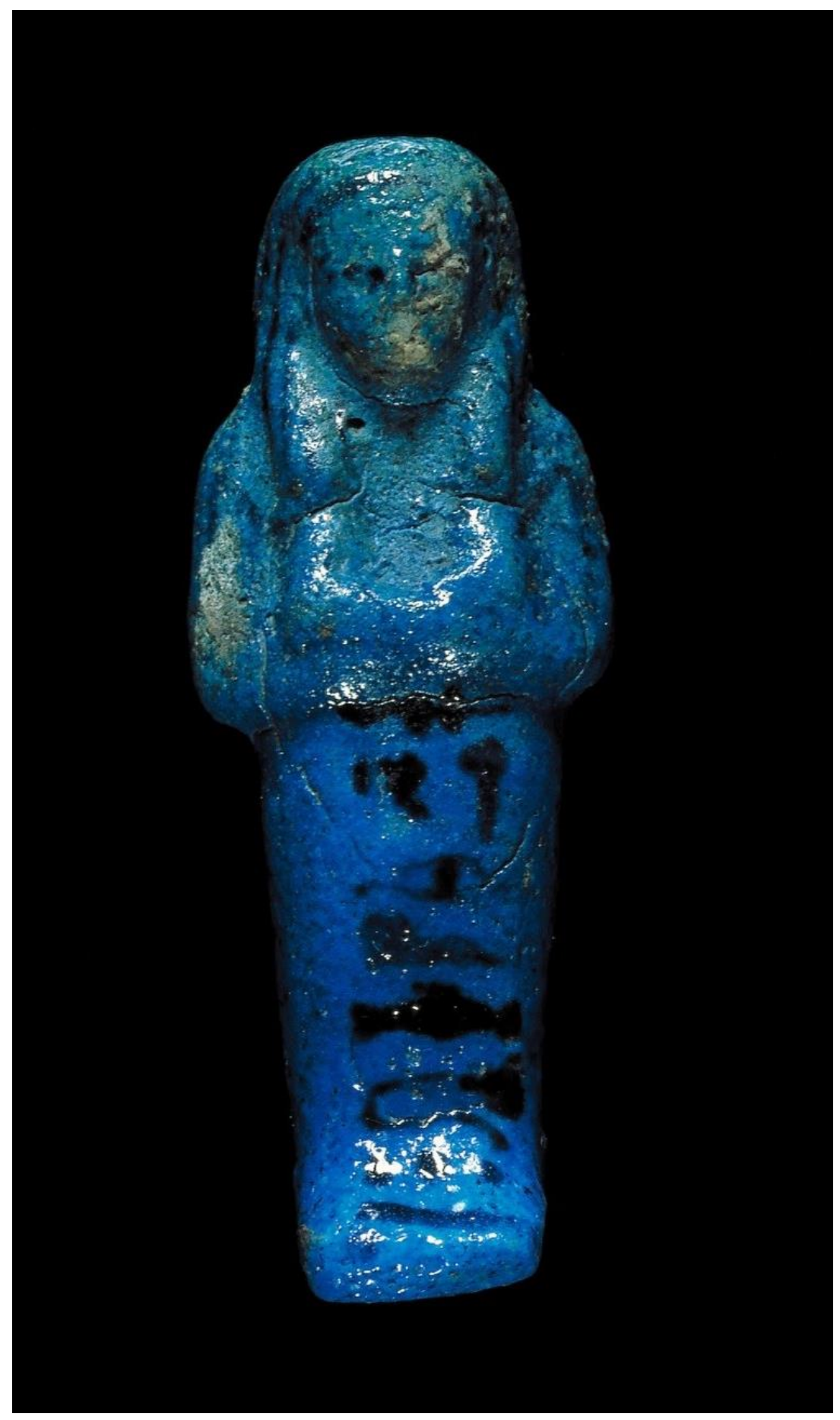

Fig. 7 Ushebti of Gautseshenu.

Photo: Museum of Cultural History, University of Oslo (C). Inv. 47076. 


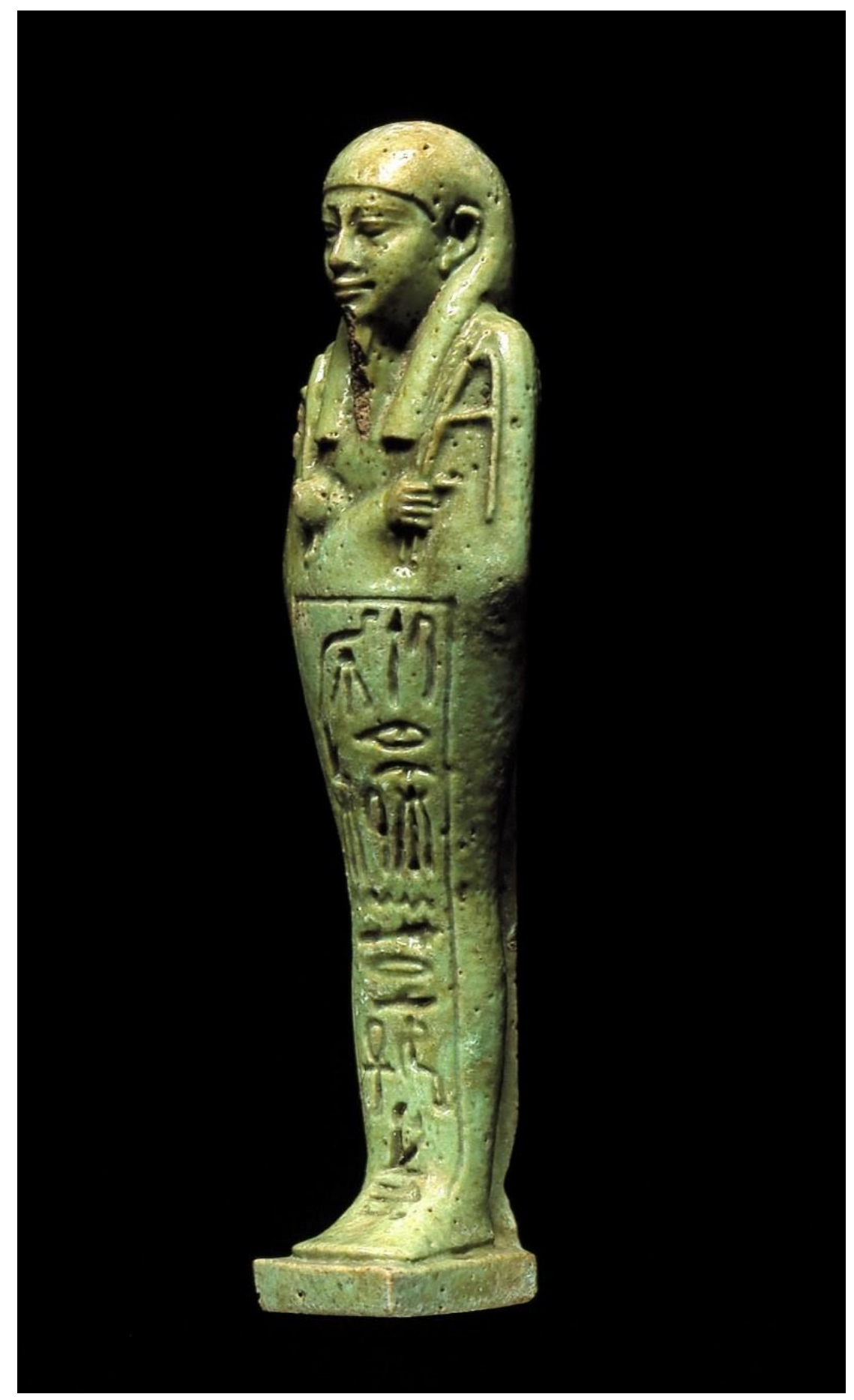

Fig. 8 Ushebti of Iahmes, son of Kheredankh.

Photo: Museum of Cultural History, University of Oslo (C) Inv. C47013. 


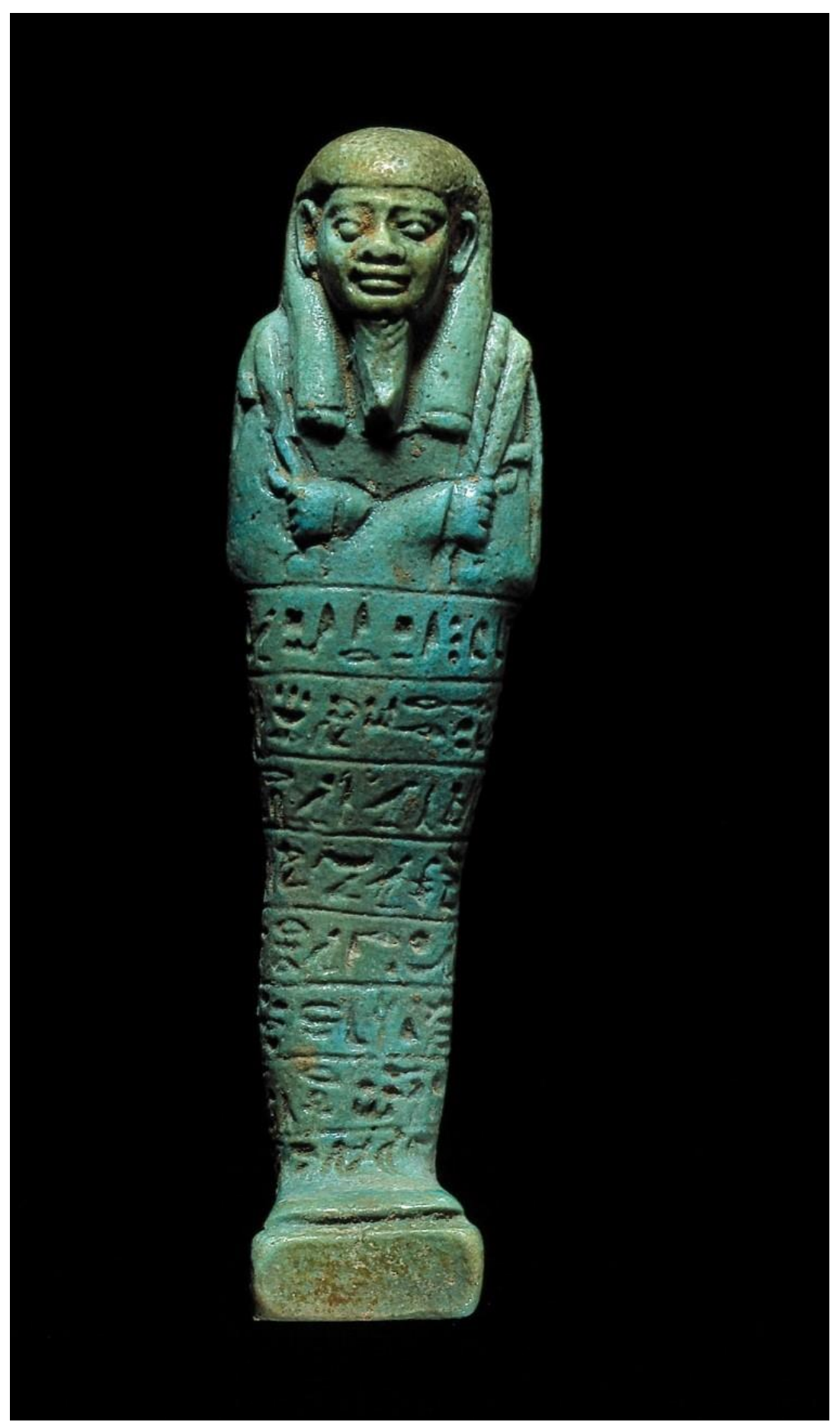

Fig. 9 Ushebti of Psamtek, son of Tagemiriset.

Photo: Museum of Cultural History, University of Oslo C. Inv. 47012. 
shoulder hangs on the back. The inscription is usually written in hieroglyphs that are incised on the body of the statuette. It reads from right to left; it consists of either an incomplete version of chapter six from the Book of the Dead written in horizontal bands, or of the sehedj-Usir formula followed by the name and title(s) of the deceased and his/her mother's name and title(s). Sometimes the name and title(s) of the father are added. ${ }^{39}$ The formula is either written vertically on the front or on the back pillar. During the twenty-seventh Dynasty (525-404 BCE) it was sometimes written in a $\mathrm{T}$-form on the front.

The $\mathrm{MCH}$ has thirty-nine ushebtis from the Late and Ptolemaic periods. Among them there is the ushebti of Iahmes, the son of a woman called Kheredankh from the twenty-sixth Dynasty (664-525 BCE). It was donated by the same Franco referred to earlier (Fig. 8). ${ }^{40}$

The same donor also gave an ushebti belonging to the 'greatest of physicians, chief of the Lybian regiment', Psamtek, son of Tagemiriset (Fig. 9). Ushebtis belonging to the same man are spread about in different museums around the world. The provenance of the artefact is unknown but the name and titles suggest that it might be Saqqara. ${ }^{41}$ The Danish shipbroker, A.J. Polack, gave, among other things, four ushebtis from the Late Period. Two belonged to the father of the god, the greatest of artificers, mayor of the city, Ankhhep, son of Nebetwadjet (Fig. 10). ${ }^{42}$

Another statuette has a T-form inscription indicating that it probably is from the twenty-seventh Dynasty with the name of the prophet of the god Horus, Paenhor, son of Renpetneferet. ${ }^{43}$ Polack also gave an ushebti that probably dates from the Ptolemaic period and belongs to the prophet of the god, the royal scribe, Nesbastet, son of Wadjit (Fig. 11). ${ }^{44}$

The consul of Sweden and Norway in Alexandria, Giovanni Anastasi (1780-1857), whose vast collection is renowned among Egyptologists and antiquities dealers, donated several ushebtis to the $\mathrm{MCH}$. There are, for instance, three statuettes of a man called Wahibra, son of Taheteret from the twenty-sixth Dynasty, two statuettes of the sem-priest, that is, a funerary priest, Wahibra-meryPtah, son of Sethet and a statuette of another sem-priest, Pasherientaihet, son of Neferrenpet. The ushebtis of Wahibra-mery-Ptah and Pasherientaihet probably date from the thirtieth Dynasty (380-343 BCE) and the names and titles of their owners suggest that the provenance is Saqqara. Lieblein gave an ushebti belonging to a

39 Only one statuette from this period at the $\mathrm{MCH}$ gives the name of the father of the deceased. It is the statuette of Hor, son of Horib, cf. Naguib 1985, 1 and 118-119 (inv. C47008/EM 311.22.i). All the other statuettes bear only the name of the deceased's mother.

${ }^{40}$ Naguib 1985, 1 and 93-94 (inv. C47013/EM2233).

${ }^{41}$ Naguib 1985, 1 and 114-115 (inv. C47012/EM2232) .

42 Naguib 1985, 1 and 95-97 (inv. C47015/EM1475 and C47016/EM1478).

${ }^{43}$ Naguib 1985, 1 and 107-108 (inv. C47020/EM2230).

${ }^{44}$ Naguib 1985, 1 and 116-117 (inv. C47014/EM 2234). 


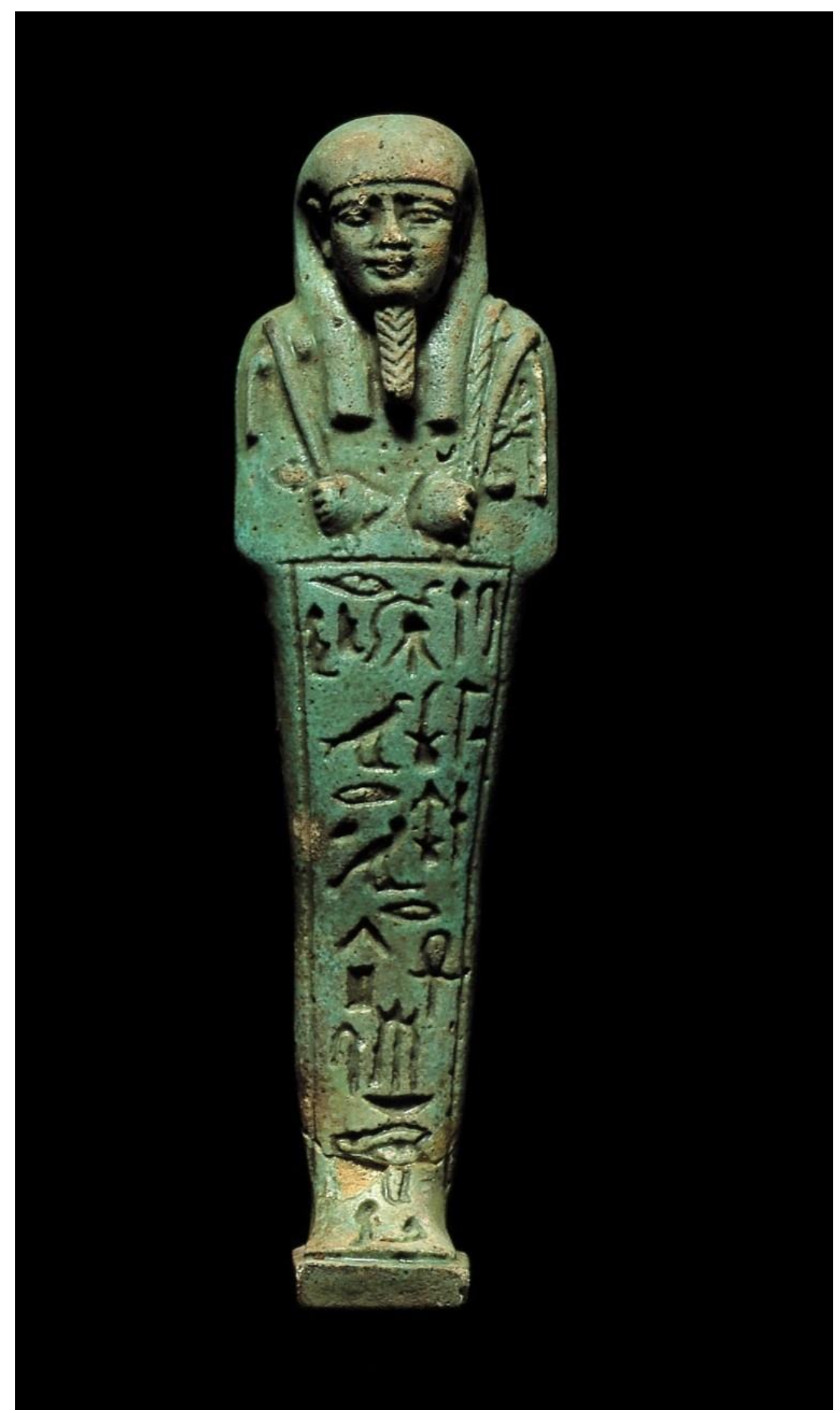

Fig. 10 Ushebti of Ankhhep, son of Nebetwadjet.

Photo: Museum of Cultural History, University of Oslo C. Inv. C47015. 


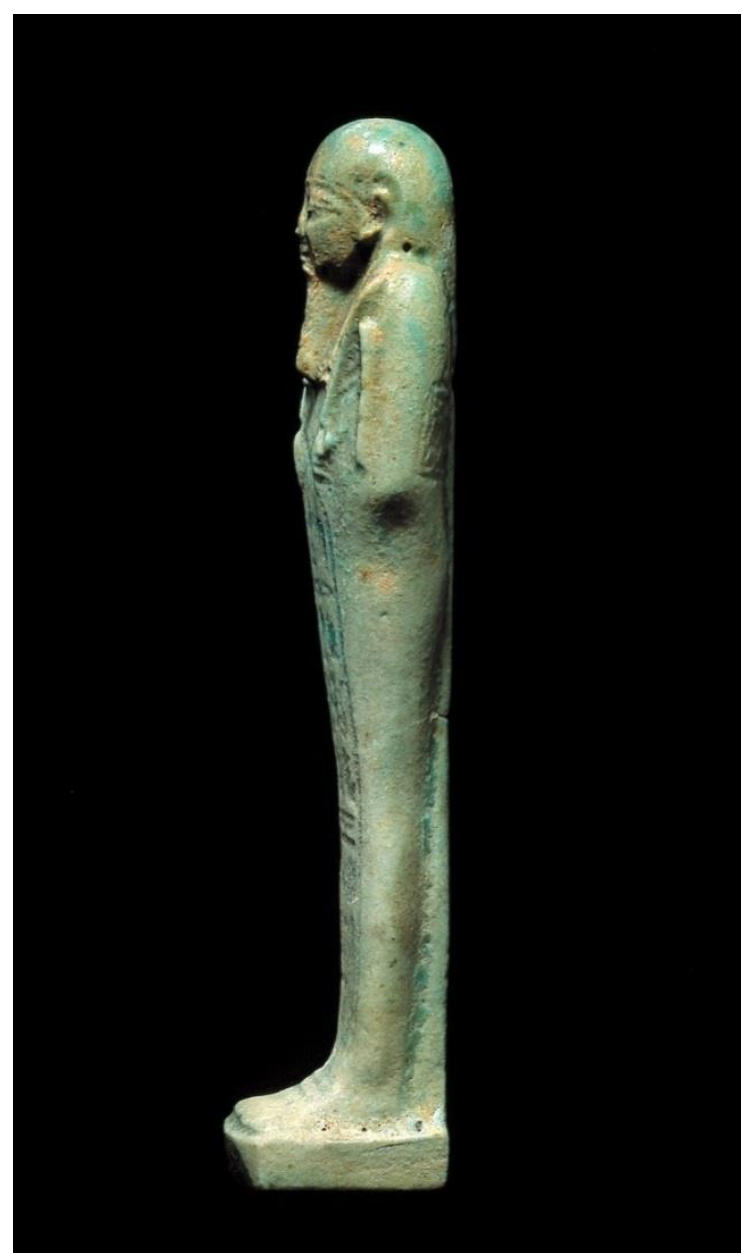

Fig. 11 Ushebti of Nesbastet, son of Wadjit. Photo: Museum of Cultural History, University of Oslo C. Inv. C47014.

certain Paiuenhor, son of Iu-Inpu, where the text is incised on the back pillar. The exact provenances of the statuettes listed above remain unknown. ${ }^{45}$

Ushebtis and numerous other artefacts representing the same individuals are often found scattered in different museums worldwide. One can only hope that future studies, new approaches to ancient Egyptian material culture and the digitization of archaeological collections in museums will bring to light new insights about the biographies and many-layered narratives of these disjecta membra.

45 Naguib 1985, 1 and 98-100 (inv. C47001/EM311.22.b; C47002/EM 311.22.c; C47003/311.22.d); 1 and 101-104 (inv. C47005/EM311.22.f/C47006/EM 311.22g); 1 and 109110 (inv. C47007/EM 311.22.h); 1 and 105-106 (inv. C47034/EM12596). 


\section{Intersecting storylines}

Issues concerning 'unprovenanced' and 'unexcavated' antiquities, ownership and cultural heritage have been the subject of many heated debates for the last fifty years or so. I shall not discuss these problems here. Suffice it to say that several ancient Egyptian artefacts at the $\mathrm{MCH}$ are unprovenanced antiquities, and as Cuno and his colleagues argue, not knowing the provenance does not make these objects meaningless. ${ }^{46}$ One has to keep in mind that they came to the museum before the adoption of the 1970 UNESCO Convention on the Means of Prohibiting and Preventing the Illicit Import, Export and Transfer of Ownership of Cultural Property. ${ }^{47}$ Today, the situation is quite different, and museum curators would be more careful and ask more questions about the origin of antiquities purchased and/or being offered to their institution. Hence, seen from museological and heritage management vantage points, issues tied to provenance and ownership do bring forth important ethical issues that add to the complexities of the artefacts in question.

The bulk of the ancient Egyptian collection at the $\mathrm{MCH}$ was acquired between 1850 and 1920. The main donors of funerary statuettes to the museum were personalities like the king of Sweden and Norway, Oscar II, and Lieblein, who together with Henrik Ibsen (1828-1906) represented Norway at the opening of the Suez canal in November 1869. Oscar II donated forty-six ancient Egyptian objects to the museum, among them forty-two funerary statuettes. ${ }^{48}$ Lieblein travelled extensively in Egypt and came into contact with a number of Europeans, Egyptologists, collectors, businessmen and antiquities dealers. Lieblein bequeathed fifty-five objects to the $\mathrm{MCH}$ of which fifteen are funerary statuettes. ${ }^{49}$ Others also contributed to the ancient Egyptian collection in Oslo. Among them there was the consul of Sweden and Norway, Giovanni Anastasi; Polack, and Franco, all of whom lived in what today is referred to as Alexandria's cosmopolitan era (1850-1960). ${ }^{50}$ Anastasi gave two mummies, several bands of linen and forty other objects to the $\mathrm{MCH}$, of which thirteen are funerary statuettes. ${ }^{51}$ Polack gave 166 ancient Egyptian objects to the $\mathrm{MCH}$ of which thirteen are funerary statuettes. ${ }^{52}$ Franco gave thirtyeight objects to the $\mathrm{MCH}$ including six funerary statuettes. ${ }^{53}$ Both Polack and Franco made their donations through the agency of Lieblein.

${ }^{46}$ Cuno 2009.

47_http://portal.unesco.org/en/ev.phpURL_ID=13039\&URL_DO=DO_TOPIC\&URL_SEC TION=201.html

48 Naguib 1981, 108; 1985, 7.

49 Naguib 1981, 108; 1985, 7.

50 Naguib 2001.

51 Naguib 1981, 108; 1985, 7.

52 Naguib 1981, 108; 1985, 7.

53 Naguib 1981, 108; 1985, 7. 
At the turn of the nineteenth century and during the early twentieth century, academic, artistic, literary, political, industrial and commercial interests converged towards and in Egypt. Several arenas or contact zones where people from different backgrounds interacted were established, and the antiquities market was such a space. They had extended social networks among the curators of various museums, antiquarians, Egyptologists, and also let it be said tomb robbers and forgerers. ${ }^{54}$ Sophisticated international and multiplex networks among antiquities dealers, academics, the consuls of the various countries and the curators of different museums were established and cultivated. And these contacts were often the foundation for the establishment and development of the various ancient Egyptian collections around the world.

Today, ancient Egyptian funerary statuettes in museums convey different meanings from those they had as part of an individual's funerary goods in antiquity. As for other artefacts that are torn from their original backgrounds, decontextualized and defunctionalized, they are either kept in the museum's storerooms and more or less forgotten or put on pedestals in exhibition rooms. There, they are used to help recreate as complete a picture as possible of an extinct culture through representation and explanation. Each item is individualized; it becomes unique. Thus, in addition to being an object of knowledge it is transformed into an art object that pertains to a common transnational cultural heritage. Studying the funerary statuettes from a biographical approach involves considering their materiality and mapping their trajectories in time and space in order to reconstruct the various networks that brought them to a given museum. It also means considering how they have been used as part of a museum collection. In our case, a short biography probes the individual life of a funerary statuette in the past, namely from when it was made and why, as well as the material it was made of, until the moment it ended up in the ground. A longer biography follows its life until the present day, that is: how, when, where and by whom it was excavated, found or bought, numbered (and re-numbered), classified, exhibited or left in the museum's storerooms. Different entry numbers reveal reorganizations within an institution and the new directions it is taking and, as has been the case for the $\mathrm{MCH}$, how it affects the status of the objects. ${ }^{55}$ Moreover, the long biography includes examining scientific analyses where all of the object's physical properties and characteristics have been considered as well as keeping up to date with the different publications that have appeared on the objects themselves and related subjects. Thus, each figurine becomes the nexus of various intersecting storylines.

In exhibitions, ancient Egyptian funerary statuettes may serve to visualise different topics relating to ancient Egypt, including aspects of daily life, society, family and kinship, professions, crafts and materials, types of foodstuff and nutrition, scripts and writing equipment or beliefs about the afterlife. The same

${ }^{54}$ Fiechter 2006, 31-44; Naguib 2007a; Thompson 2015.

55 Naguib 2007b. 
artefacts may also be used in more wide-ranging comparative exhibitions probing rituals and performances across time, the history of writing and literacy in different cultures, notions of personhood, behaviour and ethics or the history of professions. Moreover, exhibitions making use of biographic narratives may include critical presentations of excavations and compare modern archaeological methods with those of the past, in particular in colonial settings. They may, in addition, treat important matters such as forgery, illicit excavations, the trade of antiquities and thorny questions of ethics and ownership. The stories told may actually bring about novel perceptions about the notion of cultural heritage and its relevance for the present and the future.

\author{
Saphinaz-Amal Naguib \\ Professor Emerita \\ Department of Culture Studies and Oriental Languages \\ University of Oslo \\ E-mail: s.a.naguib@ikos.uio.no
}

\title{
Acknowledgements
}

This article was completed during my stay as member of the research group After Discourse: Things, Archaeology, and Heritage in the 21 Century, at the Centre for Advanced Study (CAS), the Norwegian Academy of Science and Letters, Oslo during the academic year 2016-2017. It is part of my research Archaeologies of memory and the materiality of writing within the wider project Object Matters: Archaeology and Heritage in the $21^{\text {st }}$ Century, http://objectmatters.ruinmemories.org/. I am grateful to the anonymous reviewers for their helpful comments. 


\section{Bibliography}

Armstrong, R.P. 1971: The Affecting Presence. An Essay in Humanistic Anthropology, Chicago: University of Illinois Press.

Assmann, J. 1979: Harfenlied und Horussöhne, JEg. Arch. 65: 54-77.

Assmann, J. 2001: The Search of God in Ancient Egypt, Ithaca: Cornell University Press.

Assmann, J. 2005: Death and Salvation in Ancient Egypt, Ithaca: Cornell University Press.

Aston, D.A. 2009: Burial Assemblages of Dynasty 21-25. Chronology - Typology - Developments, Wien: Verlag der Österreichschen Akademie der Wissenschaften.

Aubert, J.-F. \& L. Aubert 1974: Statuettes égyptiennes. Chaonabtis, ouchebtis, Paris : Maisoneuve.

Aubert, L. 1998: Les statuettes funéraires de la Deuxième Cachette à Deir el-Bahari, Paris : Cybèle.

Butzer, C.W. 1976: Early Hydraulic Civilization in Egypt. A Study in Cultural Ecology. Chicago: Chicago University Press.

Cuno, J. (ed.) 2009: Whose Culture? The Promise of Museums and the Debate over Antiquities, Princeton: Princeton University Press.

Faulkner, R.O. 1985 [1972]: The Ancient Egyptian Book of the Dead, London: British Museum Publications.

Fiechter, J.-J. 2005: Faux et faussaires en art égyptien (Monumenta Aegyptiaca XI), Association Égyptologique Reine Élisabeth, Turnhout: Brepols Publishers.

Gosden, C. \& Y. Marshall, 1999: The Cultural Biography of Objects, WorldArch 31:2, 169-178.

Haikal, F. 2003: Egypt's Past Regenerated by its own People, in MacDonald, S. \& M. Rice (eds), Consuming Ancient Egypt, London: UCL Press, 122-138.

Hornung, E. 1992: From Idea into Image: Essays on Ancient Egyptian Thought, Princeton: Timken Publishers.

Hornung, E. 1999: The Ancient Egyptian Books of the Afterlife, Ithaca: Cornell University Press. 
Katary, S. 2012: Land Tenure (to the End of the Ptolemaic Period), in: Garcia, J.C.M. \& W. Willeke (eds) UCLA Encyclopedia of Egyptology, Los Angeles.

http:/ / digital2.library.ucla.edu/viewItem.do?ark=21198/zz002bfks5

Kopytoff, I. 1986: The Cultural Biography of Things: Commoditization as Process, in: Appadurai, A. (ed.) The Social Life of Things: Commodities in Cultural Perspectives, Cambridge: Cambridge University Press, 64-91.

Meskell, L. 2004: Object Worlds in Ancient Egypt. Material Biographies Past and Present, Oxford: Berg.

Milde, H. 2012: Shabtis, in Willeke, W. (ed.) UCLA Encyclopedia of Egyptology, Los Angeles. http:/ / digital2.library.ucla.edu/viewItem.do?ark=21198/zz002bwv0z

Naguib, S.-A. 1981 : La collection égyptienne du musée éthnographique de l'université d'Oslo, GM 51: 107-111.

Naguib, S.-A. 1985: Funerary Statuettes. Etnografisk Museum Oslo (Corpus Antiquitatum Aegyptiacarum) Fasc. 1, Mainz am Rhein: Verlag Philipp von Zabern.

Naguib, S.-A. 1990 : Le clergé féminin d'Amon thébain à la 21e dynastie (OLA 38), Louvain: Peeters Press.

Naguib, S.-A. 1994: Interpreting Abstract Concepts: Towards an Attempt to Classify the Ancient Egyptian Notion of Person, Discussions in Egyptology 29, 99-124.

Naguib, S.-A. 1997a : Mémoire de soi. Autobiographie et identité en ancienne Egypte, in Wardini, E. (ed.), Built on Solid Rock, Studies in Honour of Professor Ebbe Egede Knudsen on the Occasion of his 65 th Birthday, April 11th 1997 (The Institute of Comparative Research in Human Culture, series B: Skrifter XCVIII) Oslo: Novus forlag, 216-225.

Naguib, S.-A. 1997b, The Weighing of the Heart: Iconic Image and Symbol, in Braarvig, J. \& T. Krogh (eds) In Search of Symbols (Occasional Papers 1), Oslo: Department of Culture Studies, University of Oslo \& Novus forlag, 68-88.

Naguib, S.-A. 2001: Modelling a Cosmopolitan Womanhood in Egypt (1850-1950). The Role of Nannies and French Catholic Girl Schools, Acta Orientalia 62, 92-106.

Naguib, S.-A. 2007a: The Shifting Values of Authenticity and Fakes, PalArch's Journal of Archaeology of Egypt/Egyptology 2/1:1-8. www.PalArch.nl.

Naguib, S.-A. 2007b : Autres temps, autres regards. Représentations de l'altérité au musée d'Histoire culturelle de l'université d'Oslo (1904-2006), Histoire de l'Art 60,149-160. 
Naguib, S.-A. 2011: Et blikk på Egypt. Neo-faraonisme og sekularisering av det offentlige rom, in Naguib, S.-A. \& B. Rogan (eds.), Materiell kultur og kulturens materialitet, Oslo: Novus, 125-144.

Nicholson, P.T., 2009: Faience Technology, in Dieleman, J. \& W. Willeke (eds.), UCLA Encyclopedia of Egyptology, Los Angeles. (http://repositeries.edlib.org/nele/uce/1082).

Schneider, H. 1977: Shabtis. An Introduction to the History of Ancient Egyptian Funerary Statuettes with a Catalogue of the Collection of Shabtis in the National Museum of Leiden 3 vols, Leiden: Rijksmuseum van oudheden te Lieden.

Shaw, I. 2001: The Oxford History of Ancient Egypt, Oxford: Oxford University Press.

Smith, M. 2009: Democratization of the Afterlife, in Dieleman, J. \& W. Willeke (eds), UCLA Encyclopedia of Egyptology, Los Angeles. (http://repositeries.edlib.org/nele/uce/1147)

Taylor, J.H. 2001: Death and the Afterlife in Ancient Egypt, London: The British Museum Press.

te Velde, H. 1990: Some Remarks on the Concept 'Person' in the Ancient Egyptian Culture, in Kippenberg, H.G., Kuiper, Y.B. \& A.F. Sander (eds) Concepts of Person in Religion and Thought, Berlin: Mouton de Gruyter, 83-101.

Thompson, J. 2015: Wonderful Things. A History of Egyptology 2: The Golden Age 1881-1914, Cairo: The American University in Cairo Press.

Tilley, C. 2006: Objectification, in Tilley, C., Keane, W., Küchler, S., Rowlands, M. \& P. Spyer (eds) Handbook of Material Culture, London: Sage, 60-73. 